\title{
Majalah Elektronik Materi Rambatan Kalor untuk Meningkatkan Minat Belajar Peserta Didik
}

\author{
Nadia Srikandi ${ }^{*}$, Ino Angga Putra ${ }^{1}$, Novia Ayu Sekar Pertiwi ${ }^{1}$ \\ ${ }^{1}$ Program Studi Pendidikan Fisika, Universitas KH. A. Wahab Hasbullah, Jombang, Indonesia \\ *e-mail korespondensi: srikandi752@gmail.com \\ (masuk: 08-01-2020; revisi: 10-06-2020; diterima: 15-06-2020)
}

\begin{abstract}
Abstrak: Masalah yang menjadi kajian dalam penelitian ini adalah kurangnya pemanfaatan media belajar yang menyebabkan peserta didik merasa bosan yang mengakibatkan menurunnya minat belajar pada peserta didik. Dengan adanya masalah tersebut diperlukan adanya majalah elektronik untuk meningkatkan minat belajar peserta didik. Tujuan dari penelitian ini adalah untuk menghasilkan produk majalah elektronik materi rambatan kalor, mengetahui kelayakan majalah elektronik materi rambatan kalor dan mengetahui peningkatan minat belajar peserta didik terhadap penggunaan majalah elektronik materi rambatan kalor. Penelitian ini merupakan penelitian dan pengembangan yang menggunakan metode dari Sugiyono. Instrumen yang digunakan berupa lembar validasi oleh validator, angket respon peserta didik dan angket minat belajar peserta didik. Hasil analisis data dari angket validasi ahli media mendapat persentase $81,6 \%$, validasi ahli materi mendapat persentase $75,3 \%$, validasi pendidik mendapat persentase $80 \%$ dan hasil uji coba peserta didik mendapat persentase $86,4 \%$. Hal ini menunjukkan bahwa majalah elektronik layak untuk digunakan. Hasil uji minat belajar sebelum penggunaan media sebesar 70,1\% yang tergolong kategori cukup. Setelah penggunaan media belajar, hasil uji minat belajar peserta didik sebesar $77,4 \%$ yang tergolong kategori baik. Hal ini menunjukkan bahwa minat belajar peserta didik meningkat setelah menggunakan majalah elektronik.
\end{abstract}

Kata kunci: Majalah elektronik; media belajar; minat belajar; rambatan kalor

\section{PENDAHULUAN}

Ilmu Pengetahuan Alam (IPA) adalah pengetahuan yang dirumuskan dan sistematis, yang berhubungan dengan gejala-gejala kebendaan dan didasarkan atas pengamatan induksi. (Fitriyati dkk., 2017) menyatakan bahwa Ilmu Pengetahuan Alam (IPA) merupakan ilmu yang mempelajari tentang gejala alam berupa fakta, konsep dan hukum yang telah teruji kebenarannya melalui suatu rangkaian penelitian. Pembelajaran IPA mengarah pada dua sudut pandang yaitu IPA sebagai produk pembelajaran dan IPA sebagai proses pembelajaran (Tala \& Vesterinen, 2015; Waldrip dkk., 2010). Pembelajaran IPA tidak hanya untuk menghafalkan konsep, hukum dan teori tetapi berhubungan dengan mengidentifikasi alam secara sistematis yang merupakan bentuk proses penemuan (Nurjanah dkk., 2018; Tias, 2017). Apabila peserta didik tidak dapat mengonstruksi konsep secara mandiri maka akan hanya menjadi objek pasif dalam pembelajaran yang hanya menerima pengetahuan saja (Fitriyati dkk., 2017).

Berdasarkan hasil wawancara dengan peserta didik MAN 3 Jombang, menunjukkan bahwa pelajaran IPA khususnya fisika adalah pelajaran yang sulit dipahami karena terlalu banyak rumus, kurang menarik dan belum memahami keterkaitan fisika dalam kehidupan sehari-hari. Pelajaran Fisika juga dianggap sebagai pelajaran yang menjenuhkan (Supardi dkk., 2015). Ketidaksesuaian pemilihan metode pembelajaran dan bahan ajar yang digunakan oleh guru menjadi 
permasalahan pada prose pembelajaran (Fitriyati dkk., 2017). Belum maksimalnya dalam pemanfaatan sumber belajar baik oleh guru maupun peserta didik menjadi kendala dalam proses pembelajaran (Mulyani, 2018). Kendala-kendala tersebut yang memungkinkan peserta didik menjadi tidak aktif dalam proses pembelajaran (Tias, 2017).

Rambatan kalor merupakan materi yang mengajarkan tentang fenomena perpindahan energi pada suatu bahan yang terjadi karena adanya perbedaan gradien (suhu) sehingga tercapainya kesetimbangan panas (Rokhimi \& Pujayanto, 2015). Ada tiga jenis perpindahan panas (energi kalor) yaitu konduksi, konveksi dan radiasi (Carey dkk., 2008; Pathare \& Pradhan, 2010; Rokhimi \& Pujayanto, 2015). Materi rambatan kalor ini sering dirasa sulit bagi peserta didik dikarenakan peserta didik hanya belajar teori saja dan tidak ada pengaplikasian dengan alam sekitar (Novia, 2018). Hasil penelitian (Pathare \& Pradhan, 2010) menunjukkan adanya miskonsepsi yang dihadapi oleh peserta didik pada teori mekanisme perpindahan kalor dan teori kinetik gas. Pembelajaran yang memiliki banyak konsep seperti pada materi rambatan kalor diperlukan alat bantu berupa media pembelajaran.

Upaya mendukung proses

pembelajaran fisika maka perlu penggunaan teknologi informasi dan komputer didalamnya yaitu penggunaan smartphone. Penggunan smartphone ini dapat digunakan sebagai fasilitas pembelajaran yang dapat memudahkan penyampaian materi kepada peserta didik secara luas tanpa dibatas ruang dan waktu (Chatterjee, 2014; Susilawati dkk., 2019). Pemanfaatan media smartphone diharapkan dapat membantu peserta didik menerima dan memahami semua materi pelajaran dan membantu guru dalam menyampaikan materi pelajaran (Mulyani, 2018). Salah satunya adalah majalah elektronik memanfaatkan media sosial Steller.

Implementasi media sosial pada proses pembelajaran memberikan dampak yang baik bagi peserta didik. Beberapa penelitian telah menunjukkan hal tersebut. Penggunaan media sosial dapat meningkatkan interaksi peserta didik baik dengan peserta didik lainnya maupun dengan guru (Moll dkk., 2015). Media sosial Facebook dapat meningkatkan hasil belajar peserta didik pada topik tata surya (Susilawati dkk., 2019). (Mulyani, 2018) menyatakan bahwa pengunaan aplikasi android dapat meningkatkan hasil belajar peserta didik. Tujuan penelitian ini yaitu a) mengetahui kelayakan media majalah elektronik dan b) mengetahui minat belajar peserta didik terhadap penggunaan media majalah elektronik.

\section{METODE PENELITIAN}

Penelitian pengembangan majalah elektronik ini merupakan jenis penelitian Research \& Development dengan mengadopsi model yang dikembangkan oleh (Sugiyono, 2013). Tahapan yang dilakukan hanya 6 tahap dari 10 tahap yaitu a) potensi dan masalah, b) pengumpulan data, c) desain produk, d) validasi desain, e) uji coba pemakaian, dan f) revisi produk.

Produk yang dihasilkan adalah majalah elektronik materi rambatan kalor melalui aplikasi Steller. Tahap validasi dilakukan oleh ahli materi, ahli media dan pendidik. Setelah media majalah elektronik telah direvisi, maka dilakukan uji coba produk secara terbatas kepada 14 orang peserta didik di MAN 3 Jombang kelas X, XI, dan XII, dan 16 orang peserta didik di SMK Kreatif Hasbullah kelas X, XI, dan XII.

Uji coba produk dilakukan untuk mengumpulkan data yang berupa respon peserta didik tentang keefektifan majalah elektronik yang telah dikembangkan dan peningkatan minat belajar peserta didik. Data yang diperoleh digunakan untuk menyempurnakan produk yang dikembangkan dan diperbaiki untuk menghasilkan produk baru yang layak digunakan sebagai media belajar.

Subjek uji coba pada penelitian ini adalah ahli materi, ahli media, pendidik dan peserta didik. Ahli materi 
memberikan komentar dan saran terkait materi. Ahli media memberikan komentar dan saran terkait media. Pendidik memberikan komentar dan saran terhadap media majalah elektronik. Peserta didik memberikan respon terhadap media belajar yang telah disajikan.

Instrumen pengumpulan data pada penelitian ini yaitu a) lembar validasi berupa angket (kuesioner) untuk mengetahui kelayakan media majalah elektronik dan b) lembar angket minat belajar peserta didik untuk mengetahui minat belajar peserta didik setelah menggunakan media majalah elektronik. Persentase kelayakan produk disajikan pada Tabel 1 dan persentase minat belajar peserta didik disajikan pada Tabel 2 .

Tabel 1. Pedoman Skala Persentase Kelayakan Produk

\begin{tabular}{ll}
\hline \multicolumn{1}{c}{ Persentase (\%) } & \multicolumn{1}{c}{ Kriteria } \\
\hline $81-100$ & Sangat Layak \\
$61-80$ & Layak \\
$41-60$ & Cukup Layak \\
$21-40$ & Tidak Layak \\
$0-20$ & Sangat Tidak Layak \\
\hline & (Riduwan, 2007)
\end{tabular}

Tabel 2. Kriteria Persentse Minat Belajar

\begin{tabular}{lc}
\hline \multicolumn{1}{c}{ Persentase (\%) } & \multicolumn{1}{c}{ Kategori } \\
\hline $75 \leq \mathrm{x} \leq 100$ & Baik \\
$55 \leq \mathrm{x} \leq 74$ & Cukup \\
$41 \leq \mathrm{x} \leq 54$ & Kurang Baik \\
Kurang dari $40 \%$ & Tidak Baik \\
\hline & (Arikunto, 2010)
\end{tabular}

\section{HASIL DAN PEMBAHASAN}

Hasil penelitian ini berdasarkan model penelitian yang dikembangkan oleh Sugiyono secara terbatas yaitu tahap 1 sampai tahap 7, sebagai berikut:

a. Potensi dan Masalah

Tahap potensi dan masalah diperoleh berdasar hasil analisis wawancara dengan peserta didik. Hasil dari wawancara dengan peserta didik diperoleh bahwa kegiatan belajar mengajar hanya menggunakan buku sebagai media belajar.

b. Mengumpulkan Informasi

Tahap mengumpulkan informasi melalui wawancara dengan peserta didik dan studi pustaka terkait materi. Hasil wawancara dengan peserta didik menunjukkan media belajar yang digunakan oleh pendidik hanya buku paket dan proses belajar belum menggunakan media belajar terutama dengan memanfaatkan media sosial sebagai media belajar. Studi pustaka terkait materi ini menggunakan sumber informasi berupa buku, video dan link. Buku yang digunakan sebagai sumber informasi yaitu buku paket untuk peserta didik dengan judul "Pintar Belajar Fisika untuk SMA/MA kelas XI" cetakan Sagufindo Kinarya dan buku dengan judul "Perpindahan Panas" oleh Agus Hariyanto. Video yang digunakan sebagai sumber informasi adalah video dari youtube yang linknya sudah tertera pada media belajar dan beberapa video hasil karya dari peneliti.

c. Desain Produk

Langkah-langkah penyusunan desain media menyesuaikan standar kompetensi, kompetensi dasar, dan indikator Fisika materi Rambatan Kalor.

Tahap pengembangan majalah elektronik dilakukan dengan bantuan media sosial Steller yang berfungsi untuk membuat desain majalah elektronik sebelum diunggah. Adapun tahap pembuatan desain sebagai berikut:

1. Akses Steller melalui smartphone dan laptop atau PC pada laman https://steller.co.

2. Pembuatan konten pada akun Steller melalui smartphone.

3. Unggah konten yang telah dibuat pada akun Steller.

Tampilan majalah elektronik dapat dilihat pada gambar. Gambar 1 (a) dan 1 (b) menunjukkan proses pembuatan majalah elektronik. Gambar 2 menunjukkan cover majalah elektronik pada subbab. Gambar 3 menunjukkan pendahuluan pada materi. Ditampilkannya pertanyaan yang berkaitan dengan materi bertujuan untuk memberikan pandangan kepada peserta didik sebelum memasuki materi yang akan dipelajari. 


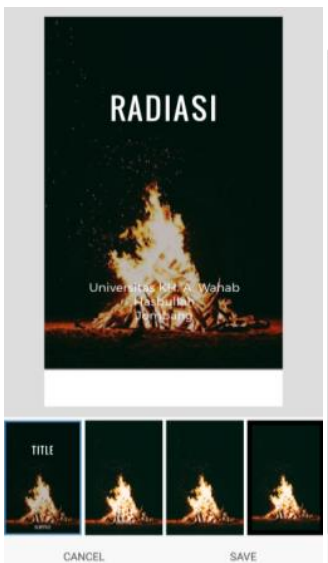

(a)

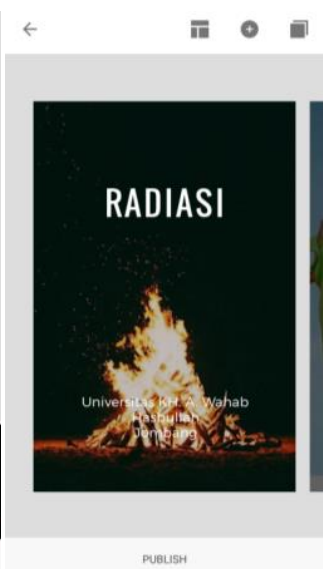

(b)
Gambar 1. Proses Pembuatan Majalah Elektronik

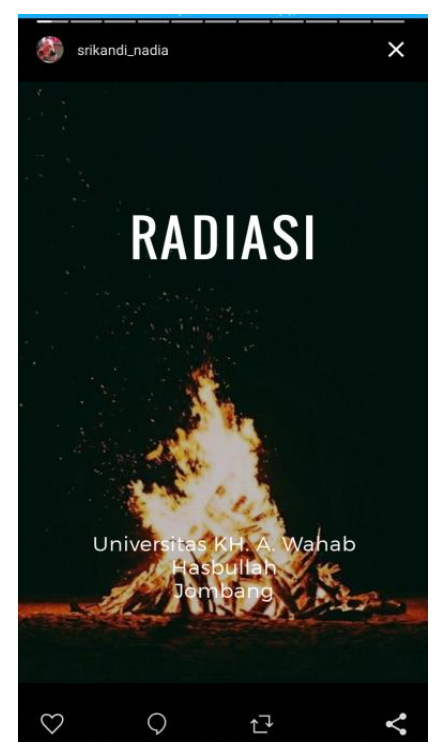

Gambar 2. Cover Pada Subbab

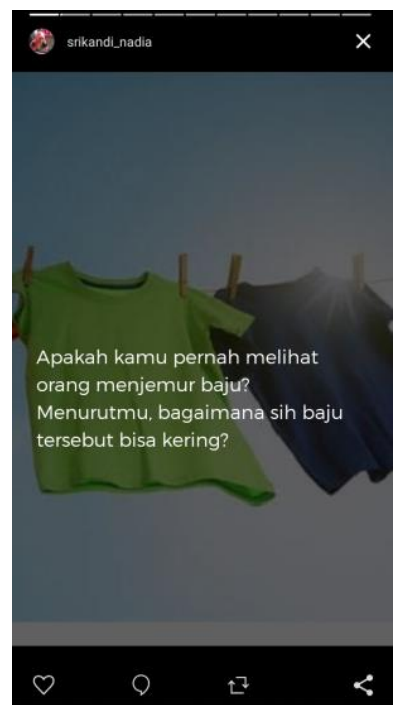

Gambar 3. Pendahuluan Pada Subbab

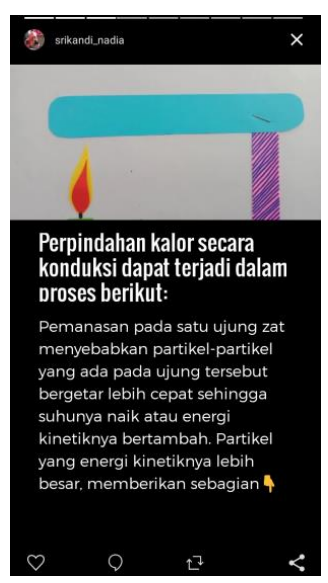

Gambar 4. Materi Pembelajaran dengan Video Ilustrasi

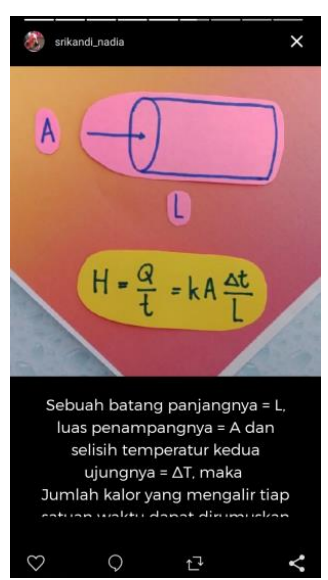

Gambar 5. Video Rumus

Gambar 4 menunjukkan materi pembelajaran. Materi pembelajaran berisi pengertian secara umum dan penjelasan tiap subbab yang ditampilkan, video ilustrasi dan video rumus. Video ilustrasi menampilkan visualisasi dari masingmasing subbab yang dijelaskan. Video rumus pada tiap subbab yang ditampilkan berbentuk video stop motion. Video Rumus dapat dilihat pada Gambar 5 .

a. Validasi Desain

Tahap ini dilakukan oleh ahli media, ahli materi dan pendidik mata pelajaran Fisika. Hasil validasi dari validator disajikan pada Tabel 5 dan Tabel 6.

Tabel 5. Hasil Validasi dari Validator

\begin{tabular}{lll}
\multicolumn{1}{c}{ Validasi } & \multicolumn{1}{c}{ Persentase } & $\begin{array}{c}\text { Kriteria } \\
\text { Penilaian }\end{array}$ \\
\hline Ahli Media & $81,6 \%$ & Sangat Baik \\
Ahli Materi & $75,3 \%$ & Baik \\
Pendidik & $80 \%$ & Baik \\
\hline
\end{tabular}


Tabel 6. Komentar dan Saran Validator

\begin{tabular}{|c|c|}
\hline Validator & Kritik dan Saran \\
\hline $\begin{array}{l}\text { Ahli } \\
\text { Media }\end{array}$ & $\begin{array}{llr}\text { a. } & \text { Cari penyebab aplikasi } \\
\text { ketika dibuka di } & \text { smartphone tiba-tiba keluar }\end{array}$ \\
\hline $\begin{array}{l}\text { Ahli } \\
\text { Materi }\end{array}$ & $\begin{array}{l}\text { a. Perbaiki imbuhan pada tiap } \\
\text { kata } \\
\text { b. Jeda waktu lebih lama pada } \\
\text { video rumus } \\
\text { c. Penambahan tugas untuk } \\
\text { peserta didik pada slide } \\
\text { terakhir }\end{array}$ \\
\hline Pendidik & $\begin{array}{l}\text { a. Penambahan alamat web } \\
\text { yang valid agar dapat } \\
\text { diakses peserta didik }\end{array}$ \\
\hline
\end{tabular}

Tabel 5 menunjukkan bahwa media belajar tergolong baik untuk digunakan sebagai media belajar peserta didik. Validasi media oleh ahli menunjukkan bahwa media belajar tergolong sangat baik digunakan untuk media belajar peserta didik. Validasi materi oleh ahli menunjukkan bahwa materi termasuk dalam kriteria baik digunakan untuk media belajar. Hasil validasi oleh pendidik menunjukkan bahwa media belajar tergolong dalam kategori baik. Meskipun hasil dari para validator tergolong dalam kategori sangat baik dan baik, tetapi masih diperlukan perbaikan sesuai kritik dan saran dari validator.

b. Revisi Desain

Revisi desain dilakukan berdasarkan kritik dan saran dari validator. Revisi dilakukan 3 kali sebelum diuji coba. Revisi pertama, produk diperbaiki berdasarkan hasil dari ahli media. Revisi kedua, dilakukan berdasarkan kritik dan saran dari ahli materi. Kemudian dilanjutkan dengan revisi ketiga berdasarkan penilaian dari pendidik.

c. Uji Coba Produk

Uji coba dilakukan secara terbatas yang terdiri dari 16 orang peserta didik MA dan 14 orang peserta didik SMK. Data hasil uji coba disajikan pada Tabel 7 .

Tabel 7. Data Hasil Uji Coba Terbatas

\begin{tabular}{|c|c|c|}
\hline Aspek Penilaian & $\begin{array}{c}\text { Jumlah Skor Tiap } \\
\text { Aspek }\end{array}$ & $\begin{array}{c}\text { Jumlah Skor } \\
\text { Maksimal }\end{array}$ \\
\hline Pemrograman & 8.7 & 10 \\
\hline Isi & 17.8 & 20 \\
\hline Tampilan & 16.1 & 20 \\
\hline $\begin{array}{l}\text { Kesesuaian sajian dengan } \\
\text { tuntutan pembelajaran }\end{array}$ & 13.6 & 15 \\
\hline Jumlah Skor & 56.2 & 65 \\
\hline Persentase & \multicolumn{2}{|c|}{$86.4 \%$} \\
\hline Kriteria Penilaian & \multicolumn{2}{|c|}{ Sangat Baik } \\
\hline
\end{tabular}

Hasil uji coba terbatas menunjukkan bahwa majalah elektronik materi rambatan kalor tergolong kategori sangat baik digunakan untuk media belajar. Akan tetapi pada aspek pemrograman dan tampilan mendapat kritikan dari peserta didik. Pada aspek pemrograman, video dapat ditampilkan dengan baik, tetapi ada peserta didik yang kesulitan karena ukuran video kurang besar. Pada aspek tampilan, ada beberapa halaman dimana background tidak sesuai dengan pembahasan.

d. Revisi Produk

Revisi produk dilakukan 1 kali berdasarkan kritik dan saran dari peserta didik. Selanjutnya, dilakukan uji minat belajar pada peserta didik. Adapun hasil uji minat belajar dapat dilihat pada Tabel 8.

Hasil angket minat belajar peserta didik sebelum menggunakan majalah elektronik diperoleh besarnya minat belajar peserta didik adalah sebesar 70,1\% yang tergolong kategori cukup. Hasil angket minat belajar setelah menggunakan majalah elektronik, minat belajar peserta didik sebesar $78,4 \%$ yang tergolong kategori baik. Hasil uji minat peserta didik menunjukkan peningkatan sebesar $8,3 \%$ dan perubahan kategorii menjadi kategori baik. 
Tabel 8. Hasil Uji Minat Peserta Didik

\begin{tabular}{lllll}
\hline \multirow{2}{*}{\multicolumn{1}{c}{ Indikator }} & \multicolumn{2}{c}{ Sebelum } & \multicolumn{2}{c}{ Setelah } \\
\cline { 2 - 5 } & Persentase & Kategori & Persentase & Kategori \\
\hline Perasaan Senang & $70.3 \%$ & Cukup & $76.7 \%$ & Baik \\
Keterlibatan & $71.4 \%$ & Cukup & $78.3 \%$ & Baik \\
Ketertarikan & $70.0 \%$ & Cukup & $76.1 \%$ & Baik \\
Perhatian & $68.6 \%$ & Cukup & $82.5 \%$ & Baik \\
\hline Rata-rata & $70.1 \%$ & Cukup & $78.4 \%$ & Baik \\
\hline
\end{tabular}

Peningkatan minat belajar peserta didik setelah menggunakan media majalah elektronik ini didukung dari beberapa hasil penelitian yang identik dalam penggunaan media sosial di dalam pembelajaran. Media sosial didalam pembelajaran memberikan sugesti kepada peserta didik untuk belajar lebih aktif dan dapat merubah perilaku peserta didik dengan cenderung ke arah positif (Abbas dkk., 2019; Hardono dkk., 2019; Irfan dkk., 2019; Rosli dkk., 2015). Media sosial dapat mempengaruhi minat belajar melalui komunikasi dan respon yang terbangun pada peserta didik saat proses pembelajaran (Abbas dkk., 2019; Alzedjali dkk., 2014). Media sosial juga dapat melatih interaksi peserta didik dan menjadi alat bantu (study support) peserta didik dalam belajar (Putra, 2016; Silius dkk., 2010).

Majalah elektronik ini memiliki kelebihan dan kekurangan. Adapun kelebihan dari majalah elektronik yaitu (1) Majalah elektronik sangat mudah digunakan, (2) Dapat digunakan dimana saja dan kapan saja, (3) Dapat memberikan pengalaman belajar baru kepada peserta didik, (4) dapat menambah informasi bagi siapapun yang membacanya, (5) Pendidik dapat membuat konten dan mengkreasikan materi yang akan diajarkan atau hanya sekedar berbagi informasi kepada masyarakat. Kekurangan dari majalah ini yaitu (1) Majalah elektronik ini hanya bisa dakses ketika smartphone atau PC dalam keadaan tersambung dengan jaringan internet, jika smartphone atau PC tidak tersambung dengan jaringan internet, maka majalah elektronik tidak dapat diakses, (2) Pada beberapa smartphone, jika mengakses Steller melalui aplikasi terkadang terjadi gangguan seperti aplikasi yang tiba-tiba keluar sehingga harus mengakses dari awal kembali untuk membuka majalah elektronik, (3) Pembuatan konten pada aplikasi Steller hanya bisa dilakukan melalui smartphone saja dan pengguna harus memiliki akun di media sosial Steller, (4) Jika menggunakan laptop atau PC, pengguna tidak bisa membuat konten yang diinginkan meskipun pengguna tersebut sudah memiliki akun di media sosial Steller.

\section{SIMPULAN}

Media majalah elektronik ini layak digunakan. Hasil kelayakan melalui tahap validasi ahli media dengan persentase $81,6 \%$, validasi ahli materi dengan persentase $75,3 \%$, dan validasi pendidik dengan persentase $80 \%$ serta melalui tahap uji coba terbatas oleh peserta didik dengan persentase $86,4 \%$. Hasil uji minat peserta didik menunjukkan adanya peningkatan minat belajar sebesar 7,3\% dimana persentase rata-rata minat belajar sebelum menggunakan majalah elektronik sebesar 70,1\% (kriteria cukup) dan persentase rata-rat minat belajar setelah menggunakan majalah elektronik, persentase meningkat menjadi $77,4 \%$ (kriteria baik).

Beberapa hal yang perlu diperhatikan pada penelitian ini, yaitu 1) Majalah elektronik dapat dikembangkan pada materi fisika yang lain. 2) Desain media dapat dirancang lebih menarik. 3) Untuk peneliti yang berikutnya dapat mengembangkan dan menggunakan majalah elektronik untuk dilakukan penelitian dengan skala 
yang lebih luas dan dapat disebarluaskan secara massal, dan 4) akses jaringan internet yang baik agar dapat digunakan oleh guru dan peserta didik.

\section{Referensi}

Abbas, J., Aman, J., Nurunnabi, M., \& Bano, S. (2019). The impact of social media on learning behavior for sustainable education: Evidence of students from selected universities in Pakistan. Sustainability (Switzerland), 11(6), $1-23$.

https://doi.org/10.3390/su11061683

Al-zedjali, K. H., Al-harrasi, A. S., \& Albadi, A. H. (2014). Motivations for Using Social Networking Sites by College Students for Educational Purposes. International Journal of Social, Education, Economics and Management Engineering, 8(8), 2551-2554.

Arikunto, S. (2010). Prosedur Penelitian Pendekatan Praktik Edisi Revisi VI. In Rineka Cipta.

Carey, V. P., Chen, G., Grigoropoulos, C., Kaviany, M., \& Majumdar, A. (2008). A review of heat transfer physics. Nanoscale and Microscale Thermophysical Engineering, 12(1), $1-60$.

https://doi.org/10.1080/15567260801 917520

Chatterjee, S. (2014). A Sociological Outlook of Mobile Phone Use in Society. International Journal of Interdisciplinary and Multidisciplinary Studies, 1(6), 5563. http://www.ijims.com

Fitriyati, I., Hidayat, A., \& Munzil. (2017). Pengembangan Perangkat Pembelajaran IPA untuk Meningkatkan Kemampuan Berpikir Tingkat Tinggi dan Penalaran Ilmiah Siswa Sekolah Menengah Pertama. Jurnal Pembelajaran Sains, 1(1), 27-34.

Hardono, A., Sarayar, A. R. O., Kurniawan, H. A., Donianxon, R. A., \& Nastiti, P. (2019). Pengaruh Penggunaan Media Sosial

Terhadap Minat $\begin{array}{r}\text { Belajar } \\ \text { Mahasiswa UAJY. }\end{array}$ Proceeding
SINTAK 2019, 1, 458-464.

Irfan, M., Nursiah, S., \& Rahayu, A. N. (2019). Pengaruh Penggunaan Media Sosial (Medsos) Secara Positif Terhadap Motivasi Belajar Siswa SD Negeri Perumnas Kecamatan Rappocini Kota Makassar. Publikasi Pendidikan, 9(3), 262. https://doi.org/10.26858/publikan.v9 i3.10851

Moll, R. F., Nielsen, W., \& Linder, C. (2015). Physics Students' Social Media Learning Behaviours and Connectedness. International Journal of Digital Literacy and Digital Competence, 6(2), 16-35. https://doi.org/10.4018/ijdldc.201504 0102

Mulyani, E. W. S. (2018). Dampak Pemanfaatan Aplikasi Android Dalam Pembelajaran Bangun Ruang. Kwangsan: Jurnal Teknologi Pendidikan, 6(2), 122136.

https://doi.org/10.31800/jtp.kw.v6n2 .p122--136

Novia, S. (2018). Pengembangan Alat Peraga Sub Materi Perpindahan Kalor secara Radiasi untuk Menunjang Pembelajaran Fisika. Inovasi Pendidikan Fisika, 7(2), 118-122.

Nurjanah, S., Wicaksono, I., \& Budiarso, A. S. (2018). Kajian Pembelajaran IPA dengan Model Pengintegrasian. Seminar Nasional Pendidikan Fisika $2018 \quad$ "Implementasi Pendidikan Karakter Dan IPTEK Untuk Generasi Millenial Indonesia Dalam Menuju SDGs 2030," 3, 341346.

Pathare, S. R., \& Pradhan, H. C. (2010). Students' misconceptions about heat transfer mechanisms and elementary kinetic theory. Physics Education, 45(6), 629-634. https://doi.org/10.1088/00319120/45/6/008

Putra, I. A. (2016). Facebook sebagai 
Media Pembelajaran yang Inovatif, Interaktif, dan Komunikatif di dalam Pengembangan Kualitas Pembelajaran. Eduscope, 1(2), 7984.

Riduwan. (2007). Skala Pengukuran Variabel-variabel Penelitian. In Alfabeta, Bandung.

Rokhimi, I. N., \& Pujayanto. (2015). Alat Peraga Pembelajaran Laju Hantaran Kalor Konduksi. Prosiding Seminar Nasional Fisika Dan Pendidikan Fisika (SNFPF), 6, 270-274.

https://doi.org/10.1186/s12870-0150414-8

Rosli, M. S., Saleh, N. S., Aris, B., Ahmad, M. H., Sejzi, A. A., \& Shamsudin, N. A. (2015). E-Learning and Social Media Motivation Factor Model. International Education Studies, $9(1)$, 20. https://doi.org/10.5539/ies.v9n1p20

Silius, K., Miilumäki, T., Huhtamäki, J., Tebest, T., Meriläinen, J., \& Pohjolainen, S. (2010). Students ' Motivations for Social Media Enhanced Studying and Learning Kirsi Silius * Thumas Miilumäki Jukka Huhtamäki Teemo Tebest Joonas Meriläinen Seppo Pohjolainen. Knowledge Management \& E-Learning: An International Journal, 2(1), 51-66.

Sugiyono. (2013). Metode Penelitian Pendidikan Pendekatan Kuantitaif, Kualitatif, dan R\&DSugiyono. https://doi.org/10.1. In Metode Penelitian Pendidikan Pendekatan Kuantitaif, Kualitatif, dan R\&D. https://doi.org/10.1007/s13398-0140173-7.2

Supardi, S. U. S., Leonard, L., Suhendri, H., \& Rismurdiyati, R. (2015). Pengaruh Media Pembelajaran dan Minat Belajar Terhadap Hasil Belajar Fisika. Formatif: Jurnal Ilmiah Pendidikan MIPA, 2(1). https://doi.org/10.30998/formatif.v2i 1.86

Susilawati, Sari, I. W., Studi, P., Fisika, P., Kuala, U. S., Pasca, P.,
Universitas, S., \& Kuala, S. (2019). Pembelajaran Fisika Berbantukan Media Sosial Facebook dan Dampaknya Terhadap Hasil Belajar Fisika. Jurnal Pendidikan Fisika, 7(1), 1-14.

Tala, S., \& Vesterinen, V. M. (2015). Nature of Science Contextualized: Studying Nature of Science with Scientists. Science and Education, 24(4), 435-457. https://doi.org/10.1007/s11191-0149738-2.

Tias, I. W. U. (2017). Penerapan Model Penemuan Terbimbing Untuk Meningkatkan Hasil Belajar Ipa Siswa Sekolah Dasar. DWIJA CENDEKIA: Jurnal Riset Pedagogik, 1(1), 50-60. https://doi.org/10.20961/jdc.v1i1.130 60.

Waldrip, B., Prain, V., \& Carolan, J. (2010). Using multi-modal representations to improve learning in junior secondary science. Research in Science Education, 40(1), 65-80. https://doi.org/10.1007/s11165-0099157-6. 